\title{
The Dynamics of Organizational Culture in the Private, Government, and Semi-Government Companies in Poland
}

\author{
Habte Woldu, Magdalena Biederman ${ }^{* *}$
}

This paper examines the dynamics of culture in Poland in three phases by measuring multilevel cultural dimensions. The first phase examines cultural changes over time, the second phase looks at cultural dynamics by comparing Polish respondents with those of USA and Russia, and the third phase looks into organizational cultural dynamics by analyzing respondents in five types of Polish business organizations. The business organizations include government, semi government, and cooperatives, domestic private and foreign owned companies (joint ventures and wholly owned companies). The study found that there are cultural dynamics within certain demographic groups and the five different Polish business organizations, however the dynamics are still most strongly influenced by the preexisting national cultural backgrounds.

In dieser Arbeit wird mit Hilfe einer Betrachtung vielschichtiger kultureller Dimensionen die Dynamik der polnischen Kultur in drei Schritten untersucht. Der erste Schritt widmet sich den kulturellen Veränderungen im Laufe der Zeit. Im zweiten Schritt wird die kulturelle Dynamik vor dem Horizont eines Vergleichs von polnischen Befragten mit US-amerikanischen und russischen Befragten betrachtet. Im dritten Schritt nun wird die organisatorische und kulturelle Dynamik anhand einer Analyse von Befragten aus fünf verschiedenartigen polnischen Unternehmen betrachtet. $\mathrm{Zu}$ diesen Unternehmenstypen gehören staatliche und halbstaatliche Unternehmen, genossenschaftliche Unternehmen und Privatunternehmen mit polnischem oder ausländischem Eigentümer. Das Ergebnis der Studie zeigt, daß es innerhalb bestimmter demographischer Gruppen und innerhalb der fünf polnischen Unternehmenstypen kulturelle Dynamik gibt. Diese Dynamik ist jedoch noch immer stark von alten nationalen kulturellen Hintergründen bestimmt.

${ }^{*}$ manuscript received: 3.3.1999, accepted: 20.8.1999

${ }^{* *}$ Woldu, Habte Giorgis, 20th March, 1954; Ph.D. in Economics, Senior Lecturer; School of Management, University of Texas at Dallas, Department of Organization, Strategy \& International Management (OSIM); main research topics: "Measuring cultural differences across countries and its impact on management perspectives"; "Dynamics of culture within groups of people and organisations"; "Regional approach to convergence of cultures"; "Cultural dynamics within Ex-Eastern European countries". 


\section{Introduction}

Poland is one of the few Ex-Soviet Satellites of Central Europe whose economic restructuring programs and economic development are worth applauding (Vlencia, 1999), but the conditions under which the country existed prior to these success stories were exceptionally difficult. In early 1980, when Solidarity, the Polish workers' union movement under Lech Walesa, protesting against the Communist Party and the system, marched in the streets of Gdansk and occupied the country's largest employer, Gdansk Shipyard, the country was on the verge of breaking up. The Ex-Soviet Union was then a superpower and a real threat, the country was heavily indebted, the economy was suffering from hyperinflation, and the nation was divided between two antagonistic parties, the ruling Communist Polish Worker's United Party (PZPR) and opposition Solidarity Movement (Kostera and Wicha, 1996). In spite of these challenges, in the early 1990s, Poland was being cited as the model for others: Balcerowicz's privatization program and monetary and fiscal policies were not necessarily popular but successful. The country managed to control the hyperinflation, the staggering unemployment rate and before long, the country became the center of foreign investment and trade between the West and East (Razvigorova and Djaroava, 1991; Benedek, 1991; Murrell, 1993). As a result, today Poland is attracting thousands of workers from the neighboring countries. In fact, the future is even estimated to be brighter. Its economy, which has been growing by $7 \%$ for several years, is going to continue in the future (Vlencia, 1999).

What are the reasons behind Poland's success? Some say it was the special treatment Poland got from the West through IMF and World Bank that helped the programs of Balcerowicz work while Murrell (1993) says, it was the special path to a free market economy that countries like Poland and China chose which is helping (Dorinbusch, 1997; Yeung and Tung, 1996); while others think, it is the continuing presence of the catholic ethic - though less than perfect - which helps in raising the honesty of businessmen and the ordinary workers. This is something, which is present in lesser degrees in the other Ex-Soviet territories (Fry, 1996; Vlencia, 1999). The unique varied cultural influences upon Poland in the last two centuries created a cultural synergy, which is a condition for communication with the outside world (Adler, 1997; Miller, 1995), and certainly was helpful in the creation of successful joint ventures (Pry and Faminsky, 1991; Maciejko, 1991; Lucas, 1998) in Poland and other East European countries. Nevertheless studies indicate that foreign investors complain about the problems faced by expatriates in their international assignments (Suutari, 1998). These problems do occur in varying degrees almost in all former Eastern Bloc countries (Panov, 1991; Murrell, 1993; Kostera, 1995). As these culturerelated miscommunications are hindering the flexibility and adaptability of the international human resource, it has become important to look into national, 
organizational and professional cultures in a detailed methodical way (Hoecklin, 1995; Hofstede, 1991; Suutari, 1998; Fry, 1996; Gurkov, 1996; Panov, 1991; Murrell, 1993).

\section{Historical Background}

Poland is a unique East European country with regard to its cultural dynamics. Historically, East and West affected the Polish national culture over a long period of time. The country is ethnically Slavic. Between 1790 and 1918, the western part of Poland received Prussian-German culture, the center and east, Russian, and the southwest Hapsburg-Austrian. After 1945, the influence of East and West over Poland continued in a slightly different way. Most of the influence came through the indoctrination of the nation by Russian Communist ideology at a government and institutional level, although the influence of the west continued in an informal way, through the individual contacts the Poles continued to have with the West. Most of the Polish contact with the West was through emigration. It is estimated that there were about 3.5 million Poles who emigrated from Poland between 1871-1913. Today, it is estimated that there are around 12 million Polish background emigrants living abroad, with 5.6 million of them just in the USA, and about 400,000 working in Germany (Rajkiewicz, 1998). The emigration between the First and Second World Wars continued but the new destinations were Canada, Argentina, and France (Rajkiewicz, 1998). After World War II, the emigration to the West has been strongly motivated by a desire for employment opportunities and higher wages so as to improve their standards of living. The Polish emigration is unique in its way that it is well connected with the socio-economic and cultural life of Poland; all classes participated, and the émigrés were encouraged to maintain their Polish identity and their contacts back home. In fact, the motto of the society is for all emigrants to come back with material achievements, without losing their morals or culture (Okolowicz, 1920). In modern times, the flow of cash to Poland from the repatriation of expatriate income is very significant. According to Rajkiewicz (1998), between 1991 and 1996, the inflow of income to Poland by expatriates from Germany alone reached the value of 6 billion DM. Beyond the material benefit the Polish expatriates brought with them indispensable expertise, know-how, and new technologies, as well as western management styles which were beneficial during the transition from a centralized economic system to a free market economy. Without this expatriate contribution the Polish economic transformation could have been much slower (Murrell, 1993).

\section{Defining Cultural Dimensions}

Culture is defined in many different ways, depending on the nature and purposes of the researcher and the research (Jelinek, Smircich, \& Hirsch, 1986; Hofstede, 
1983; Adler, 1997; Schein, 1985). Most of the definitions are derived from anthropology. Culture is all patterns of values, ideas and symbolic systems that shape behavior (Kluckhohn and Strodbeck, 1961). The definition of culture should be viewed in terms of relativity as it constantly changes (Schein, 1985; Hoecklin, 1995). The deep culture is derived from that nation's original cultural background, its formative history, and its general history until the present time. The complexity of culture and the difficulties of understanding what culture is in a concrete way arises from the dynamics of the three layers: national (NC), organizational (OC) and professional (PC) culture and their interactions as are presented in figure 1. This paper concentrates on the portions of the culture, which is a product of an overlap of the above three layers that is theoretically reflected in the business environment.

Figure 1. A Theoretical Model on Interaction of Three Layers of Culture

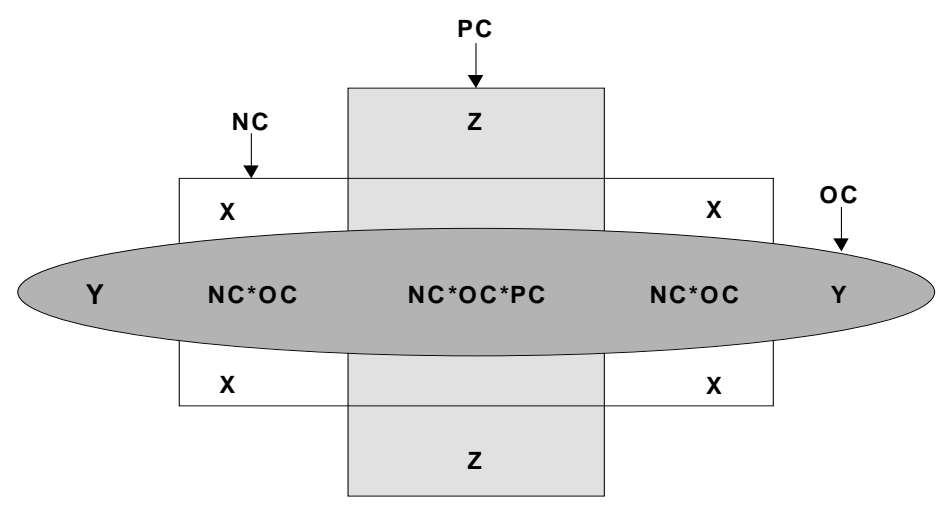

$\mathrm{NC}=$ National Culture

$O C=$ Organizational Culture

$\mathrm{PC}=$ Professional Culture

As the business organizations in Eastern Europe change in structure and form their members will undergo certain changes, but those changes may not be deep cultural changes (Hossen and Gustavsson, 1995). Russia and Poland have both suffered enormous national traumas throughout the twentieth century, and the shift from government controlled economies and political systems to open politics and free market economics in the last ten years have been the latest (Puffer, 1994). These transformations are so major and far-reaching into all of the population that they should have had visible and measurable effects on the national cultures (Gurkov, 1996; Suitor and Riusala, 1998).

The paper attempts to measure the cultural differences through four cultural perspectives in three phases. The first phase discusses the cultural differences 
over time in Poland; in phase two, Polish organizational culture is compared to that of USA and Russia; where as the third phase looks into cultural dynamics within Polish five different business organizations. The four cultural dimensions the study uses for multiple comparison are activity-doing (AD), relationcollectivism (RC), relation-hierarchy (RH), relation to nature-harmony (RNH).

Activity of doing (AD) measures the extent to which people prefer doing productive work to leisure time. High scores in AD indicates that people value activity of doing most, and emphasize work-related activities and goals expecting rewards based on achievements. This activity of doing can be directly related to the definitions of masculinity and weak uncertainty avoidance cultural dimensions as applied by Hofstede (1983).

Collective relations (RC) measures the extent to which one believes that what is good to the group is good to himself/herself. High scores in RC would mean that the society expects individuals to sacrifice their own interest for the good of all. In such a culture, individual's rewards would be based on the performance of the workgroup or unit. An individual is expected to be loyal to the group he/she belongs, and in return, the individual expects protection from everyone else.

Hierarchical relations ( $\mathrm{RH})$ is the belief that in order for any organization to function well formal structure of an organization should be kept intact. In cultures where the mean score for $\mathrm{RH}$ is high, people at higher levels of an organization will have the responsibility to make decisions for people below them and maintain a stance between leaders and followers. A high score on RH can be understood in the context of Hofstede's high power distance and strong uncertainty avoidance measurements (Hofstede, 1983).

Relations to nature harmonious (RNH) is the belief that any organization that lives in harmony with its environment - defined broadly - will function well. The culture of such a society emphasizes balance and considers the elements of the environment and the members of the society with dignity and cares for their preservation.

\section{Organizing Data and Research Method}

Based on a standardized questionnaire prepared by Maznewski, DiStefano and Nason (1995), a survey of 643 respondents, 182 from USA, 169 from Russia, and 292 from Poland (123 of them conducted in 1995 and 169 in 1999) was conducted in the respective countries. The questionnaire, which was written originally in English, was translated into Russian and Polish languages and then back to English so as to avoid any discrepancies in interpretation. The questionnaire contained 90 items. The first 79 questions corresponded with eleven cultural dimensions, and the scores for each response for the 79 items were based on a seven level Likert scale, where 1=strongly disagree and $7=$ strongly agree. The eleven remaining items provide demographic information, 
so that responses could be analyzed across countries, organizations, occupations, work experience, education levels, age groups and genders. The survey through random sampling procedure targets respondents, which were mainly people who worked for established companies or institutions in major cities. The US respondents were based in Dallas metropolitan area, the Polish came from Poznan, a major service and industrial city while the Russian survey was conducted in both St. Petersburg and Komi Republic cities; thus the targeted population in all cases is urban and worked for modern organizations and institutions.

The study was conducted in three phases. The first phase identified the change in cultural values in Poland over a four-year interval. The second phase analyzed the cultural difference among the three countries (Poland, USA and Russia) by taking into consideration the total sample population, while the third phase, which is the main emphasis of the paper, looks into the cultural value system of the sub-populations who work for the five different groups of organizations categorized by forms of business ownership in Poland. While the second phase looked into the cultural differences among the countries, the third looked into the dynamics of business organizations through the value system of the human resource employed by them. Analysis of Variance (ANOVA) followed by Student-Newman-Keuls test at significance level $p=0.05$ was used to test the cultural differences. In order to measure cultural dynamism as discussed above, the following exploratory hypotheses were tested:

H1: The cultural attitude of the Polish respondents has changed due to the socio-economic and political transformation in the last 4 years.

H2A: The general Polish human resources attitude is different than those of USA and Russia.

H2B: There are cultural differences among the managers, experienced employees, professionals and females of Poland, Russia and USA.

H3: There are cultural differences among respondents who work for the different Polish based business organizations classified by types of ownership.

\section{Phase 1 results. Cultural changes in the targeted population over a four- year period (testing $\mathrm{H} 1)$.}

Earlier studies indicated that Poland's national culture was somewhat between West and East. Based on similar survey conducted in 1995 and 1998, (Woldu, Fitzpatrick and Biederman 1999; Woldu, 1998), it was found that the Polish cultural values system differed significantly from Russian in 10 out of 11 cultural dimensions, while it differed from the US in 8 dimensions.

In order to examine whether fundamental cultural changes in Poland have taken place or not, the mean scores for the data 1995 was compared with that of 1999. Although we have not tested the same population, the business organizations 
sample populations were collected from similar business organizations and institutions in the same area. Based on t-tests for independent samples, the results showed no significance difference to indicate any cultural changes within the last four years. These findings allowed us to merge the two samples collected in different times without incurring any bias factor.

\section{Phase 2 results. The measured differences between Poland, Russia and USA (testing H2A).}

Comparative analysis of cultural differences across the three countries provided the following results.

In the activity of doing, cultural difference was observed among all three countries. The output indicates that the Polish culture can be viewed as being between East and West. Furthermore the results indicate that the Russian respondents tend to believe the most and the Americans the least in activities of doing.

In the attitude of collective relations, the study found that Poland differed from both Russian and American respondents. The Polish respondents believed most in collective behavior, while the USA showed the least, however no significant difference was found between Russia and USA.

In the attitude of hierarchical relations, all three countries differed from one another. The Polish respondents showed the highest traits of hierarchical behavior followed by Russia and the US with the least.

Table 1. Differences in cultural dimensions across countries.

\begin{tabular}{lcccccc}
\hline Measure & Country & Count & Mean/sd & USA & Russia & Poland \\
\hline Activity-doing & USA & 182 & $4.49 / 0.79$ & $*$ & $*$ \\
& Russia & 169 & $5.22 / 0.70$ & & $*$ \\
& Poland & 292 & $4.72 / 0.71$ & & \\
\hline Relation-collectivism & USA & 182 & $4.20 / 0.79$ & ns & $*$ \\
& Russia & 169 & $4.18 / 0.87$ & & $*$ \\
& Poland & 292 & $4.59 / 0.74$ & & \\
\hline Relation-hierarchy & USA & 182 & $3.27 / 0.97$ & $*$ & $*$ \\
& Russia & 169 & $4.30 / 0.85$ & & $*$ \\
\hline Relation to nature & Poland & 292 & $4.65 / 0.71$ & & \\
harmony & USA & 182 & $5.23 / 0.85$ & $*$ & $*$ \\
& Russia & 169 & $5.72 / 0.71$ & & ns \\
\hline
\end{tabular}

${ }^{*} \mathbf{p}<0.05$ based on Student-Newman-Keuls multiple comparison procedure ns=not significantly different 
In the attitude of harmony, the Polish respondents differed from the US respondents, but not from the Russians, while the American respondents who scored the least significantly differed from both.

In summary, the study in phase two found that there are cultural differences among the three countries in all dimensions except between Russia and USA in collective relations and between Poland and Russia in harmonious relations. The results of the analysis indicate that H2A is acceptable in full only in the case of activity of doing. Surprisingly, the results showed that Russian respondents tend to show behavior, which is between Poland and USA, in both collective and hierarchical.

\section{Phase 2 results. Cultural Differences among the specific demographic groups of the three countries (testing H2B).}

The reasoning behind the suggested exploratory hypothesis H2B is the assumption that while the difference among national cultures remain strong and relatively inflexible, cultural dynamics would lead towards convergence of culture in certain groups of the population (Child, 1986, Laurent, 1983, Woldu, 1998).

The hypothesis tested the behavior of groups of the population, which are expected to play an active role in the process of cultural convergence. The groups include: managers, respondents who work for professional organizations, experienced employees and females.

In activities of doing (AD), the results showed that the Polish managers compared with their counter partners from USA and Russia did not show any significant difference although the general population had shown differences (table 1 and 2). Cultural convergence was also observed in the case of Polish professional employees compared to those from USA, however, the cultural convergence between the two countries was due to an increase of the mean score by American professionals.

In collective/collateral relations (RC), there was no cultural deviation of any particular group of people from the overall cultural difference observed among the general population of the three countries. None of the Russian groups of population, which could be expected to show some convergence, showed any deviation from the value system of the national culture.

In hierarchical relations (HR), professional respondents from Poland and Russia show no significant cultural difference, that is a convergence from the original observation, shown in table 1 . This convergence is attributed more to the change in Poland than it is to Russia, as the Polish professional respondents scored significantly lower mean than the overall Polish population did. 
Table 2. Differences in cultural dimensions.

\begin{tabular}{|c|c|c|c|c|c|c|c|}
\hline Measure & Status & Country & Count & Mean/sd & USA & Russia & Poland \\
\hline \multirow{12}{*}{$\begin{array}{l}\text { Activity- } \\
\text { doing }\end{array}$} & \multirow[t]{3}{*}{ Managers } & USA & 41 & $4.63 / 0.84$ & & \multirow[t]{3}{*}{$*$} & ns \\
\hline & & Russia & 43 & $5.05 / 0.71$ & & & ns \\
\hline & & Poland & 132 & $4.88 / 0.69$ & & & \\
\hline & \multirow{3}{*}{$\begin{array}{l}\text { Respondents } \\
\text { working for } \\
\text { professional } \\
\text { organizations }\end{array}$} & USA & 68 & $4.46 / 0.79$ & & \multirow[t]{3}{*}{ * } & ns \\
\hline & & Russia & 44 & $4.99 / 0.78$ & & & $*$ \\
\hline & & Poland & 73 & $4.57 / 0.57$ & & & \\
\hline & \multirow{3}{*}{$\begin{array}{l}\text { Experienced } \\
\text { employees }\end{array}$} & USA & 92 & $4.46 / 0.78$ & & \multirow[t]{3}{*}{$*$} & $*$ \\
\hline & & Russia & 103 & $5.31 / 0.70$ & & & $*$ \\
\hline & & Poland & 152 & $4.82 / 0.65$ & & & \\
\hline & \multirow[t]{3}{*}{ Female } & USA & 79 & $4.40 / 0.88$ & & \multirow[t]{3}{*}{ * } & $*$ \\
\hline & & Russia & 73 & $5.22 / 0.73$ & & & $*$ \\
\hline & & Poland & 161 & $4.75 / 0.70$ & & & \\
\hline \multirow{12}{*}{$\begin{array}{l}\text { Relation- } \\
\text { collectivism }\end{array}$} & \multirow[t]{3}{*}{ Managers } & USA & 41 & $4.30 / 0.80$ & & \multirow[t]{3}{*}{ ns } & $*$ \\
\hline & & Russia & 43 & $4.02 / 0.70$ & & & $*$ \\
\hline & & Poland & 132 & $4.73 / 0.73$ & & & \\
\hline & \multirow{3}{*}{$\begin{array}{l}\text { Respondents } \\
\text { working for } \\
\text { professional } \\
\text { organizations }\end{array}$} & USA & 68 & $4.15 / 0.81$ & & \multirow[t]{3}{*}{ ns } & $*$ \\
\hline & & Russia & 44 & $3.92 / 0.80$ & & & $*$ \\
\hline & & Poland & 73 & $4.55 / 0.71$ & & & \\
\hline & \multirow{3}{*}{$\begin{array}{l}\text { Experienced } \\
\text { employees }\end{array}$} & USA & 92 & $4.15 / 0.89$ & & \multirow[t]{3}{*}{ ns } & $*$ \\
\hline & & Russia & 103 & $4.30 / 0.87$ & & & $*$ \\
\hline & & Poland & 152 & $4.76 / 0.87$ & & & \\
\hline & \multirow[t]{3}{*}{ Female } & USA & 79 & $4.10 / 0.81$ & & \multirow[t]{3}{*}{ ns } & $*$ \\
\hline & & Russia & 73 & $4.03 / 0.87$ & & & $*$ \\
\hline & & Poland & 161 & $4.59 / 0.70$ & & & \\
\hline \multirow{6}{*}{$\begin{array}{l}\text { Relation- } \\
\text { hierarchy }\end{array}$} & \multirow[t]{3}{*}{ Managers } & USA & 41 & $3.42 / 0.98$ & & \multirow[t]{3}{*}{$*$} & $*$ \\
\hline & & Russia & 43 & $4.40 / 0.79$ & & & $*$ \\
\hline & & Poland & 132 & $4.73 / 0.72$ & & & \\
\hline & \multirow{3}{*}{$\begin{array}{l}\text { Respondents } \\
\text { working for } \\
\text { professional } \\
\text { organizations }\end{array}$} & USA & 68 & $3.20 / 1.04$ & & \multirow[t]{3}{*}{$*$} & $*$ \\
\hline & & Russia & 44 & 4.39/0.87 & & & ns \\
\hline & & Poland & 73 & $4.41 / 0.71$ & & & \\
\hline
\end{tabular}




\begin{tabular}{|c|c|c|c|c|c|c|}
\hline & \multirow{3}{*}{$\begin{array}{l}\text { Experienced } \\
\text { employees }\end{array}$} & USA & 92 & $3.23 / 0.98$ & \multirow[t]{3}{*}{$*$} & \multirow{3}{*}{ * } \\
\hline & & Russia & 103 & $4.35 / 0.89$ & & \\
\hline & & Poland & 152 & $4.73 / 0.70$ & & \\
\hline & \multirow[t]{3}{*}{ Female } & USA & 79 & $3.12 / 1.03$ & \multirow[t]{3}{*}{$*$} & * \\
\hline & & Russia & 73 & $4.08 / 0.85$ & & $*$ \\
\hline & & Poland & 161 & $4.66 / 0.71$ & & \\
\hline \multirow{12}{*}{$\begin{array}{l}\text { Relation to } \\
\text { nature } \\
\text { harmony }\end{array}$} & \multirow[t]{3}{*}{ Managers } & USA & 41 & $5.52 / 0.72$ & \multirow[t]{3}{*}{ ns } & ns \\
\hline & & Russia & 43 & $5.64 / 0.74$ & & ns \\
\hline & & Poland & 132 & $5.66 / 0.54$ & & \\
\hline & \multirow{3}{*}{$\begin{array}{l}\text { Respondents } \\
\text { working for } \\
\text { professional } \\
\text { organizations }\end{array}$} & USA & 68 & $5.33 / 0.85$ & \multirow[t]{3}{*}{$*$} & $*$ \\
\hline & & Russia & 44 & $5.70 / 0.62$ & & ns \\
\hline & & Poland & 73 & $5.67 / 0.59$ & & \\
\hline & \multirow{3}{*}{$\begin{array}{l}\text { Experienced } \\
\text { employees }\end{array}$} & USA & 92 & $5.16 / 0.80$ & \multirow[t]{3}{*}{$*$} & $*$ \\
\hline & & Russia & 103 & $5.67 / 0.74$ & & ns \\
\hline & & Poland & 152 & $5.73 / 0.52$ & & \\
\hline & \multirow[t]{3}{*}{ Female } & USA & 79 & $5.36 / 0.86$ & \multirow[t]{3}{*}{$*$} & $*$ \\
\hline & & Russia & 73 & $5.78 / 0.66$ & & ns \\
\hline & & Poland & 161 & $5.66 / 0.55$ & & \\
\hline
\end{tabular}

\section{${ }^{*} \mathbf{p}<\mathbf{0 . 0 5}$ based on Student-Newman-Keuls multiple comparison procedure ns=not significantly different}

In relations to nature-harmonious (RNH), the output shows that there is a high level of convergence (cultural similarities) among many of the sub population of the three countries. The study found that there is no cultural difference noted among the managers from the three countries, while there was one among the general population respondents of USA, Russia and Poland. The change (convergence) is caused as the result of an increase of the mean score on RNH by American managers while those of Poland and Russia showed little change.

\section{Cultural differences within organizations in Poland (testing hypothesis 3)}

The study also looked into the cultural difference of diversified business organizations within Poland. Old business organizations are shrinking while some new ones are emerging. There are many government owned companies awaiting privatization. In the coming few years the government wants to privatize about 3000 companies, among them are PKO (Polish Saving Bank) and Polish LOT Airlines, (The Economist, 1999). During this transformation period, as a result of restructuring and downsizing of government and semi 
government business organizations and institutions there will be a high mobility of employees. These employees will transplant old organizational culture to the new emerging organizations. In this transition, managers need to understand the different organizational cultures that are brought in, so that in these, the cultural diversity can be positively used (Adler, 1997) in the new working environment.

Based on the types of ownership, we were able to classify the 293 respondents into five population groups. The five groups consist of: 63 respondents from the government owned companies; 76 from semi government companies (JednoOsobowa Spolka Skarbu Panstwa) are business entities which are in the process of privatization; 33 from cooperative companies (Spodzielnia); 63 from the Polish private companies; and 37 from foreign-owned companies. The cultural differences among the specific groups working for these organizations were examined. In order to find the mean score differences in each cultural measure for the demographic groups in each organization, analysis of variance (ANOVA) was employed followed by Student-Newman-Keiuls multiple comparison test at $\mathrm{p}=0.05$. Based on the analysis, of the output, cultural differences were tested among the groups of managers, professionals, experienced employees and females.

In relation to manager respondents, the study showed the following important findings:

- managers who work for semi government and government organizations believed less in activities of doing (AD) than those managers who work for foreign companies operating in Poland (foreign companies include wholly owned and joint venture entities),

- managers who work for semi-government and privately owned local companies tend to believe less in hierarchy (RH) than those who work for cooperative business organizations,

- managers who work for foreign companies were found to be less harmonious (RNH) than those who work for semi-government and privately owned companies.

In relation to respondents working for professional organizations, the study found that respondents who work for foreign companies believed less in risk avoidance strategy and believed more in "do first and think later" rather than "think carefully before you act" principle, more than those who work for semigovernment and government organizations. 
Table 3. Differences in cultural dimensions among business organizations in Poland.

\begin{tabular}{|c|c|c|c|c|c|c|c|c|c|}
\hline Measure & Status & Organizat: & Count & Mean/sd & GOV & SGOV & COOP & LPC & FC \\
\hline \multirow{5}{*}{$\begin{array}{l}\text { Activity of } \\
\text { doing }\end{array}$} & \multirow[t]{5}{*}{ Managers } & GOV & 43 & $4.81 / 0.64$ & & \multirow[t]{5}{*}{ ns } & ns & ns & $*$ \\
\hline & & SGOV & 28 & 4.63/0.69 & & & ns & ns & $*$ \\
\hline & & COOP & 25 & $5.09 / 0.60$ & & & & ns & ns \\
\hline & & LPC & 26 & $4.93 / 0.63$ & & & & & ns \\
\hline & & FC & 17 & $5.31 / 0.88$ & & & & & \\
\hline \multirow{5}{*}{$\begin{array}{l}\text { Relation- } \\
\text { hierarchy }\end{array}$} & & GOV & 43 & $4.77 / 0.70$ & & \multirow[t]{5}{*}{ ns } & ns & ns & ns \\
\hline & & SGOV & 28 & $4.56 / 0.74$ & & & $*$ & ns & ns \\
\hline & & COOP & 25 & $5.21 / 0.44$ & & & & $*$ & ns \\
\hline & & LPC & 26 & $4.62 / 0.72$ & & & & & ns \\
\hline & & FC & 17 & $4.87 / 0.76$ & & & & & \\
\hline \multirow{5}{*}{$\begin{array}{l}\text { Relation to } \\
\text { nature- } \\
\text { harmony }\end{array}$} & & GOV & 43 & $5.67 / 0.71$ & & \multirow[t]{5}{*}{ ns } & ns & ns & ns \\
\hline & & SGOV & 28 & $5.79 / 0.56$ & & & ns & ns & $*$ \\
\hline & & COOP & 25 & $5.58 / 0.44$ & & & & ns & ns \\
\hline & & LPC & 26 & $5.82 / 0.41$ & & & & & $*$ \\
\hline & & FC & 17 & $5.32 / 0.67$ & & & & & \\
\hline \multirow{5}{*}{$\begin{array}{l}\text { Activity of } \\
\text { doing }\end{array}$} & \multirow[t]{5}{*}{ Female } & GOV & 38 & $4.93 / 0.68$ & & \multirow[t]{5}{*}{ ns } & ns & ns & ns \\
\hline & & SGOV & 35 & $4.44 / 0.54$ & & & $*$ & ns & ns \\
\hline & & COOP & 16 & $5.09 / 0.62$ & & & & ns & ns \\
\hline & & LPC & 33 & $4.76 / 0.76$ & & & & & ns \\
\hline & & FC & 19 & $4.88 / 0.81$ & & & & & \\
\hline \multirow{5}{*}{$\begin{array}{l}\text { Relation- } \\
\text { hierarchy }\end{array}$} & & GOV & 43 & $4.77 / 0.70$ & & \multirow[t]{5}{*}{$*$} & ns & ns & $*$ \\
\hline & & SGOV & 28 & $4.56 / 0.74$ & & & $*$ & ns & ns \\
\hline & & COOP & 33 & $5.21 / 0.44$ & & & & $*$ & $*$ \\
\hline & & LPC & 26 & $4.62 / 0.72$ & & & & & ns \\
\hline & & FC & 17 & 4.87/0.76 & & & & & \\
\hline \multirow{5}{*}{$\begin{array}{l}\text { Relation- } \\
\text { hierarchy }\end{array}$} & Experienced & GOV & 43 & $4.79 / 0.71$ & & \multirow[t]{5}{*}{ ns } & ns & ns & ns \\
\hline & Employees & SGOV & 55 & $4.54 / 0.64$ & & & $*$ & ns & ns \\
\hline & & COOP & 17 & $5.13 / 0.55$ & & & & ns & ns \\
\hline & & LPC & 22 & $4.85 / 0.76$ & & & & & ns \\
\hline & & $\mathrm{FC}$ & 11 & $4.71 / 0.60$ & & & & & \\
\hline
\end{tabular}

${ }^{*} \mathbf{p}<0.05$; ns= not significantly different; GOV= Government owned; SGOV=Semi government owned; COOP $=$ Cooperative; $L P C=$ Local Polish capital; FC= Foreign capital

In relation to female respondents, the study found that females who work for semi-government organizations believed less in doing (AD) than female 
respondents who work for cooperatives while females who work for foreign and semi government owned companies believed less in RH than those who work for government owned and cooperatives.

\section{Conclusion}

The finding of the paper conveys a variety of messages, which can be addressed to researchers and businessmen who are interesting in understanding the dynamics of culture in the current Polish business organizations.

In spite of the dynamics of economic growth, successful privatization programs and the rapidly improving standard of living the nation has been enjoying, it seems that the current Polish national and organizational cultures do not seem to fit either the West or the East nor is between East and West in all cultural dimensions. The most important finding of this study and which is worth further research is the observation that the Polish respondents were found to manifest more hierarchical and collective traits than either USA or Russia. The hierarchical and collective behavior of Central Eastern European respondents is supported by earlier studies (Fogel, 1994; Soulby and Clark, 1996; Bollinger, 1994). This would suggest that while Poland is probably heading towards a free market economy, it's not necessarily following the classical capitalist path, which is naturally non-hierarchical and non-collective (Hofstede, 1983). On the other hand, the finding of Polish managers and professionals, unlike the overall population, showed little difference from the respective groups in the USA in $\mathrm{AD}$, which indicates that the Polish corporate leaders seem to operate in the mindset of the West; such observation also clearly supports the notion that cultural dynamism within certain groups of the business sector exists. Furthermore, although the study did not find cultural dynamic changes between the observation of the overall data collected in 1995 and 1999, from the output of the study in phase 3, it was possible to learn that there is cultural dynamism within the currently existing business organizations in Poland. The study found that managers who work for semi government and government owned businesses seemed to believe less in activity of doing more than the managers who work for foreign owned companies, whereas, respondents from foreign companies believed less in harmonious cultural behavior when compared with the locally owned companies. These findings can be important factors to be considered by foreign investors when hiring local managers, establishing joint venture entities as well as during business acquisitions (Stuuri, 1998). Finally, it is worth mentioning that cultural differences are not limited only to foreign and local business organizations; for example, the study found that respondents from semi government and local private business organizations were significantly different in hierarchy from the respective groups of population working for Polish cooperatives; the latter was found to show more hierarchical traits. 


\section{References}

Adler, N., International Dimensions of Organizational Behavior, International Thomas Publishing, Ohio, 1997

Benedek, T., "East-West Joint Venture”, in Razvigorova, E. and Wolf-Laudon, G. (eds.), East-West Joint Ventures: The New Business Environment, Blackwell, Finance Pub., Cambridge, Massachusetts, 1991

Bollinger, D., "The Four Cornerstones and Three Pillars in the "House of Russia" Management System”. Journal of Management Development 13, 49-54, 1994

Child, J. "Culture, Contingency and Capitalism in the Cross-National Study of Organization., In L. L. Cummings and B.M. Staw, eds., Research in Organizational Behavior,” Vol. 3 (Greenwich, Coo.: Jai Press, 1981, pp.303-356

Dorinbusch, R., “Don’t Let This Weird Bunch Dictate America’s China Policy”, Business Week; June 16, 1997, p.24

Elenkov, D., "Differences and Similarities in Managerial Values between U.S. and Russian Managers”, Int. Studies of Mgt. \& Org., Vol. 27, No.1, spring 1997, pp85-106

Fry, C., "Key Success Factors for Russian-Foreign Joint Ventures" The International Executive, Vol. 38 no. 3., May/June 1996, pp.337-357

Fogel, D.S. (ed.). Managing in emerging market economies: Cases from the Czech and Slovak republic. Westview Press, Boulder, Co. 1994

Gurkov, I., "Changes of control and Business Reengineering in Russian Privatized Companies”, The International Executive, Vol. 38 no. 3., May/June 1996, pp.359-388

Hoecklin, L., Managing cultural Differences: strategies for Competitive Advantage, AddisonWesley Publishing Company, New York, 1995

Hofstede, G., Cultures and Organizations: Software of the Mind. London: McGraw-Hill, 1991

Hofstede, G., "National Cultures in Four Dimensions”, International Studies of Management \& Organization, Vol. XIII, No. 1-2, pp.46-74; 1983

Hossen, D., Gustavsson, P., Competition by Effective Management of Cultural Diversity, International Studies of Management and Organization, Vol. 22, No. 4, pp.81-92, 1995

Kluckhohn, F. and Strodtbeck, F. L., Variations in Value Orientations., Connecticut, Greenwood Press, 1961

Kostera, M. and Wicha, M., "The 'Divided Self' of Polish State-owned Enterprises: The Culture of Organizing", Organization Studies, No. 17/1, pp.83-105, 1996

Kostera, M., Differing Managerial Responses to Change in Poland, Organization Studies, 1995, 16/4, pp.673-697

Laurent, A., “The Cultural Diversity of Western Conceptions of Management”, International Studies of Management \& Organization, Vol. XIII, No. 1-2 pp.75-96, 1983

Lucas, E., "Eastern Europe: Time To Smarten Up”, The World in 1998, An Economist Publication; The Economist, 1998; p.44 
Maciejko, R., “Joint Ventures in Poland”, in Razvigorova, E. and Wolf-Laudon, G. (eds.), East-West Joint Ventures: The New Business Environment, Blackwell, Finance Pub., Cambridge, Massachusetts, 1991

Maznevski, M., DiStefano and Nason, "The Cultural Perspectives Standardized Questionnaire", University of Virginia; 1995.

Miller, K., Organizational Communication, Wadsworth Publishing Company, New York, 1995

Murrell, P., "What is Shock Therapy? What Did it Do in Poland and Russia”, Post-Soviet Affairs, 1993, pp. 111-140, 1993

Okolowicz, J., Wychodzstwo and Osadnictwo Polskie przed Wojna, Warszawa, 1920

Panov, O., "Radical Changes in the Economies of Socialist Countries: A Driving Force for East-West Cooperation”, in Razvigorova, E., and Wolf-Laudon, G. (eds.): East-West Joint Ventures: The New Business Environments; Blackwell Finance Pub.; Cambridge, Mass.; pp. 3-15

Pry, R. and Faminsky, I., “Joint Ventures: Bridge Between East and West”, in Razvigorova, E., and Wolf-Laudon, G. (eds.), East-West Joint Ventures: The New Business Environment, Blackwell, Finance Pub., Cambridge, Massachusetts, 1991

Puffer, S.M, "Understanding the Bear: A Portrait of Russian Business Leaders”, Academy of Management Executives, 1994, Vol.8 No. 1

Rajkiewicz, A., "Procesy Migracji, Zarobkowej w Polsce”, Akademica Ekonomiczna w Poznaniu, Zeszyty Naukowe, no. 1/265, pp. 90-107, Poznan, Poland, 1998I/265, 1998

Razvigorova, E., and Djarova, J., "East-West Joint Ventures: Current Practices and Problems”, in Razvigorova, E., and Wolf-Laudon, G. (Eds.) East-West Joint Ventures: The New Business Environment, Blackwell, Finance Pub., Cambridge, Massachusetts, 1991

Schein, E.H., Organizational Culture and Leadership, San Francisco: Jossey Bass., 1985

Soulsby, A. and Clark, E., "The emergence of post-communist management in the Czech Republic”, Organization Studies 17, pp227-247

Suutari, V., “Leadership behavior in Eastern Europe”, The International Journal of Human Resource Management, 9:2 April, 1998, pp. 235-258

Suutari, V., "Problems Faced by Western Managers in Eastern Europe”, JEEMS 3/1998, pp.249-267

Suutari, V., and Riusala, K., "Leadership Styles in Central Eastern Europe: Experiences of Finnish Expatriates in Czech Republic, Hungary and Poland,” Scandinavian Journal of Management, (Submitted for consideration in 1998)

Trompenaars, F., Riding the Waves of Culture. London: The Economist Books, 1993

Vlencia, M., “Eastern Europe's sad duet”, The Economist: The World in 1999 (Special Report), pp. 57-58

Woldu, H., "Measuring How Cultural Perspectives Differ Across Countries: The Impact of Cultural Differences on Management Styles”; 1998, (Proceeding paper for the 1998 IHRM Conference in Paderborn, Germany) 
Woldu, H., and Gao, I., "Understanding Cultural Differences Between Russia and North America”, Management Education for Countries in Transition, Macmillan Publishers, London, 1998 (in press)

Woldu, H., Fitzpatrick, S., and Biederman, M., "How Poland Differs from East and West in Cultural Perspectives”; Zeszyty Naukowe, Jan. 1999 (in press)

Yanouzas, J., and Boukis, S., "Transporting Management Training into Poland: Some Surprises and Disappointments”, Journal of Management Development; vol. 12, no. 1, 1993; pp. 64-71

Yeung, I., and Tung, R., “Achieving Business Success in Confucian Societies: The Importance of Guanxi,” Organizational Dynamics, autumn, 1996, pp.54-65

Zelinec, M., Smircich, L., and Hirsch, P. "Introduction: A code of many colors", Administrative Science Quarterly, 28, 331-338, and 1986) 